Editorial

\title{
Biocatalysis and Pharmaceuticals: A Smart Tool for Sustainable Development
}

\author{
Andrés R. Alcántara $\mathbb{D}$ \\ Department of Chemistry in Pharmaceutical Sciences, Section of Organic and Pharmaceutical Chemistry, \\ Faculty of Pharmacy, Complutense University of Madrid, Plaza de Ramón y Cajal, s/n, E-28040 Madrid, Spain; \\ andalcan@ucm.es; Tel./Fax: +34-91-394-1820
}

Received: 16 September 2019; Accepted: 19 September 2019; Published: 23 September 2019

\section{Background}

Biocatalysis is the term used to describe the application of any type of biocatalyst (enzymes, as isolated preparations of wild-type or genetically modified variants, or whole cells, either as native cells or as recombinant expressed proteins inside host cells) in a given synthetic schedule [1]. One type of applied biocatalysis, also called a biotransformation [2], takes advantage of the excellent enzymatic precision inherent to its use, in terms of chemoselectivity, regioselectivity, or stereoselectivity. The use of biotransformations has increased considerably in recent decades, complementing classical chemical synthesis in multiple industries, mainly for the preparation of pharmaceuticals [1,3-18], fine chemicals [19-21] or food products [22-24]. Additionally, and based on the principles and metrics of green chemistry [25-29] and sustainable chemistry [30-37], biocatalysis fits perfectly into this framework; in fact, biocatalyzed procedures are highly efficient, economical, and generate less waste than conventional organic syntheses [38-46]. As such, the interest in the application of biocatalysis within the pharma industry is not surprising, as this industry is by far the biggest waste producer [43,46-50]. Furthermore, as biotransformations are generally conducted under approximately the same temperature and pressure conditions, the possibility of carrying out coupled cascade processes is enabled, providing additional economic and environmental advantages [51-58]. Finally, most biotransformations can be easily developed in standard multipurpose batch reactors without requiring costly specific devices, such as high-pressure equipment $[59,60]$, allowing the costless implementation of continuous processes [21,44,61-63].

In recent decades, the increase of the impact of biocatalysis within the pharma industry has not been linear. In fact, it was relatively minor until the last two decades, when a clear increase (the third wave of biocatalysis [64]) was caused by the popularization of the genetic manipulation of biocatalysts by directed evolution [15,65-75], a method involving fast generation of enzyme mutants using new molecular biology techniques combined with selective pressure via screening conditions. This technique, recognized by the Nobel Prize in Chemistry being awarded to pioneer Frances Arnold in $2018[76,77]$, has allowed the redesign of enzymes to fulfill industrial requirements in terms of specificity, activity, and robustness, while keeping or even increasing its outstanding precision. Thus, with this potent tool in our hands, we are facing what has been called the 4 th wave of biocatalysis $[1,78,79]$, which will be fully implemented within the pharma industry when the speed of the overall process needed to create an improved biocatalyst (rational directed evolution in a design-make-test cycle, combining multiple disciplines in a continuous industrialized workflow) is improved by at least $200 \%-1000 \%[1,18,80,81]$. 


\section{The Present Issue}

In this Special Issue, in which I have been honored to act as Guest Editor, different articles have been published covering very diverse areas of this fascinating discipline-the implementation of biocatalytic tools focused on pharmaceuticals. It comprises three reviews and eight research articles.

In the first review by Bastida and coworkers [82], the application of glycosaminoglycan (GAG)-degrading enzymes, specifically chondroitin sulfate (CS) lyases (CSases), is presented as an effective tool for the preparation of bioactive molecules possessing diverse therapeutic applications. Thus, initially the types, structures, and mechanisms of different CSases are described, and afterward, the application of these enzymes for the synthesis of low molecular weight chondroitin sulphate (LMWCS; used for osteoarthritis treatment, cardiocytoprotection, anticoagulant and antithrombotic activities, etc.) is reviewed, clearly illustrating the potential of these enzymes for the sustainable development of CS-based pharmaceutical products.

In the second review, presented by Alcántara and coworkers [83], different chemoenzymatic methods (using nitrilases, ketoreductases, and aldolases) for the synthesis of the lateral chain of statins-possessing two stereogenic centers, the absolute configuration of which is vital for the therapeutic activity of these drugs-are presented and compared. Statins-inhibitors of 3-hydroxy-3-methylglutaryl coenzyme A (HMG-CoA) reductase-are the largest selling class of drugs prescribed for the pharmacological treatment of hypercholesterolemia and dyslipidemia. In fact, the statin market involves a huge amount of money, which could potentially increase due to the recently described statins' pleiotropic effects (beneficial effects for cardiovascular health, regulation of the immune system, anti-inflammatory and immunosuppressive properties, prevention and treatment of sepsis, treatment of autoimmune diseases, osteoporosis, kidney and neurological disorders, or even in cancer therapy), which are also noted.

In a similar field, Rhimi and coworkers present in this Special Issue a review of the microbial bioreduction of cholesterol to coprostanol [84], a metabolite poorly absorbed by the human intestine, allowing it to have an impact on cholesterol metabolism and modulation of serum cholesterol levels. This biotransformation is still poorly understood, as few studies are available examining cholesterol-metabolizing bacteria and their associated genes. Thus, by understanding the molecular characterization of these bacterial pathways (currently, three different pathways are proposed), as presented in this review, it could be possible to design new hypocholesterolemic strategies that could be complementary to the previously mentioned prescription of statins.

As mentioned before, eight research articles are included in this Special Issue. In the article presented by Plou and coworkers, a controlled enzymatic hydrolysis of chitosan or chitin with different enzymes was employed to obtain three types of chitooligosaccharides (COS), with molecular weights ranging $0.2-1.2 \mathrm{kDa}-$ namely, fully deacetylated (fdCOS), partially acetylated (paCOS), and fully acetylated (faCOS) chitooligosaccharides [85]. Subsequently, the chemical composition of these biopolymers was established, as well as the anti-inflammatory activity of the three COS mixtures. In this case, this was done by measuring their ability to reduce the level of tumor necrosis factor (TNF) in murine macrophages (RAW 264.7) after stimulation with a mixture of lipopolysaccharides (LPS). Results showed that fdCOS and faCOS chitooligosaccharides effectively displayed anti-inflammatory activity, therefore proving their potentiality.

Sulfuretin is a naturally occurring aurone displaying a remarkable spectrum of biological activities (including against acquired lymphedema, anti-Parkinson's disease activity, antioxidant action, therapeutic benefits in bone disease and regeneration, as well as neuroprotective effects). Although sulfuretin glucosides are important sources of innovative drugs, few glucosides of sulfuretin have been observed in nature, meaning the preparation of sulfuretin glycosides is an attractive research field. In this sense, in the article presented by Kong and coworkers [86], the glycosyltransferase (GT)-catalyzed glycodiversification of sulfuretin is described, specifically using a flavonoid GT (named OcUGT1) for the glucosylation of sulfuretin with UDP-Glc. In this article, ten glycosylated products (three monoglucosides, five diglucosides, and two triglucosides) are characterized; the three monoglucosides 
were identified as sulfuretin $3^{\prime}-, 4^{\prime}-$, and 6-glucoside, while the major diglucoside was assigned as sulfuretin $4^{\prime}, 6$-diglucoside. The exact structures of the other four diglucosides (traces) were not well characterized, but they were inferred to be sulfuretin $3^{\prime}, 6$-diglucoside, sulfuretin $3^{\prime}, 4^{\prime}$-diglucoside, and two disaccharide glucosides. Finally, the structural identification of the remaining two triglucosides was not performed because of their small amount, although one of them was deduced to be sulfuretin $3^{\prime}, 4^{\prime}, 6$-triglucoside, according to the previously reported catalytic behavior of OcUGT1. Remarkably, at least six of the ten sulfuretin glucosides are described for the first time, making this a pioneering article in describing the simultaneous production of monoglucosides, diglucosides, and triglucosides of sulfuretin from a single glycosyltransferase.

The use of laccases for catalyzing polymerization of bioactive phenolic compounds has become very attractive because of the enhanced physicochemical and biological properties of the obtained products, which are generally used as nutraceuticals. In this context, the article presented by Eibes and coworkers [87] describes the influence of enzyme activity on rutin (also named rutoside, quercetin-3-O-rutinoside, or sophorin) oligomerization using low (1000 U/L) and high (10,000 U/L) initial activities of laccase from Trametes versicolor in a food-compatible reaction medium; rutin oligomers with the best characteristics were obtained in the reaction with the lowest laccase activity, significantly improving the apparent aqueous solubility and xanthine oxidase inhibitory activity compared to its control reaction, without compromising the antioxidant activity. The thermal stability of rutin oligomers was negatively affected by increasing the enzyme concentration, and by comparing the antioxidant capacity of similar mean molecular mass oligomers produced with different laccase activities, these authors concluded that higher enzyme dosages promoted the formation of multiple intermolecular bonds between rutin units, which negatively affected their antioxidant activity. Remarkably, this is the first study focusing on the effect of laccase activity upon the products obtained in enzymatic oligomerization of the rutin flavonoid as a key parameter to enhance and tailor their physicochemical and biological properties.

The article presented by Otero and coworkers [88] describes different extraction methods of high-value hydrophilic spirulina biocomponents (peptides of therapeutic interest), using four selective enzymatic degradations of spirulina biomass, catalyzed by two proteases and endo- and exoglucanases, illustrating the usefulness of biocatalysts in this applied field. The four enzyme-assisted extraction processes were optimized, determining best experimental conditions $(\mathrm{pH}$, temperature, enzymatic loading or duration of enzymatic pre-treatment), and scaled up, showing a superior behavior compared to those extractions not employing enzymes. The best results for hydrophilic extraction were obtained using Alcalase ${ }^{\circledR}$ (a serine endo-peptidase from Bacillus licheniformis, mainly subtilisin A), because of its effective degradation of membrane proteins, lipoproteins, and peptidoglucan under very mild conditions.

Sterically demanding 2,2-diaryl-2-hydroxy carboxylic acids are valuable chiral building blocks for the synthesis of antimuscarinic agents. When facing a hypothetical enzymatic kinetic resolution of these bulky substrates, there are two main drawbacks: First of all, esters having $\alpha$-quaternary or $\alpha$ - tertiary centers display high steric hindrance, hampering their approach to the enzymatic active site, (only pig liver esterase (PLE) has been proven active for this purpose). Additionally, esters of 2-hydroxy-2-(3-hydroxyphenyl)-2-phenylacetate (the key precursors for preparation of antimuscarinic agents) display poor stereo discrimination because of the two aromatic groups directly bound to the stereocenter, which differ only by the presence of a meta substituent on one of the two aromatic rings. For this difficult task, Pinto, Carzaniga, and coworkers [89] have described a very smart approach, using a double enzymatic hydrolysis: In fact, because in a first PLE-catalyzed hydrolysis of the quaternary $\alpha$-hydroxyester, only moderate enantioselectivity $(80 \%$ ee) was obtained, these authors chemically re-esterified the enantiomerically enriched $\alpha$-hydroxyacid and carried out a second enzymatic hydrolysis. With this methodology (optimized by choosing suited co-solvents (DMSO) and additives ( $\beta$-cyclodextrins)), it was feasible to prepare the desired optically pure $\alpha, \alpha$-diaryl- $\alpha$-hydroxyacid on a multi-milligram scale. 
Speranza, Ubiali, and coworkers present in this Special Issue a paper describing the chemoenzymatic synthesis of ribavirin, tecadenoson, and cladribine (nucleoside analogues, well-established drugs in clinical practice, mainly used as anticancer and antiviral agents) via "one-pot, one-enzyme" transglycosylation; that is, the transfer of the carbohydrate moiety from a nucleoside donor to a heterocyclic base [90]. For this purpose, purine nucleoside phosphorylase from Aeromonas hydrophila (AhPNP) was the biocatalyst used, using 7-methylguanosine iodide and its 2'-deoxy counterpart as sugar donors. Good conversions $(49 \%-67 \%)$ were achieved in all cases under screening conditions. Similarly, 7-methylguanine arabinoside iodide was prepared for the purpose of synthesizing the antiviral vidarabine via a novel approach, although neither the phosphorolysis of the sugar donor nor the transglycosylation reaction were observed. Finally, this strategy was used to prepare two other ribonucleosides structurally related to ribavirin and tecadenoson, namely, acadesine (5-aminoimidazole-4-carboxamide-1- $\beta$ - $D$-ribofuranoside, also named AICA-riboside or AICAR) and 2-chloro- $N^{6}$-cyclopentyladenosine (CCPA), leading to a moderate yield (52\%) for the latter compound only. This study clearly paves the way for the development of a new synthesis of the target Active Pharmaceutical Ingredientes APIs at a preparative scale, and contributes to the understanding of the specific substrate requirements of AhPNP.

The stereoselective synthesis of enantiopure amines is an interesting task because of their role as intermediates in pharmaceutical synthesis, as well as for a variety of other chemical products. There are several biocatalyzed approaches leading to these optically pure amines using different enzymes (amine dehydrogenases, imine reductases, reductive aminases, or amine transaminases). Two contributions in this Special Issue focus on this area. Campos, Gotor-Fernández, and coworkers apply a broad panel of commercially available amine transaminases (ATAs) for the biotransanimation of 3,4-dihydro-2H-1,5-benzoxathiepin-3-one (the chemical synthesis of which is reported via some previously undescribed intermediates) to furnish the correspondent enantiopure amines [91]. The optimization of the reaction conditions (enzyme loading, temperature, and reaction times) using ATA03 from Neosartorya fischeri and ATA07 from Mycobacterium vanbaalenii (leading to the $(S)$-amine), as well as TA-P1-G05 for the $(R)$-counterpart, allowed a milligram-scale synthesis of the pure amines, which are useful as building blocks for the preparation of antiproliferative drugs.

In the second article producing enantiopure amines, Hollmann and coworkers report a methodology based on the aerobic photooxidation (mediated by water-soluble sodium anthraquinone-2-sulfonate (SAS) and heterogeneous graphitic carbon nitride $\left(\mathrm{g}-\mathrm{C}_{3} \mathrm{~N}_{4}\right)$ ) of primary and racemic secondary alcohols to the corresponding aldehydes and prochiral ketones, which are subsequently transformed into the (chiral) amines with commercial aminotransaminases (one $(R)$ and four $(S)$-ATAs), using isopropylamine as the sacrificial amine donor [92]. The system worked in a one-pot, one-step fashion; as time-consuming intermediate isolation and purification steps were omitted, the required amount of organic solvents was minimized, with a concomitant reduction of waste. The productivity was significantly improved by switching to a "one-pot, two-step" procedure. A wide range of aliphatic and aromatic compounds was transformed into the enantiomerically pure corresponding amines via the photo-enzymatic cascade, providing good yields and excellent ee values.

In conclusion, these eleven papers clearly illustrate the versatility of biocatalysis in the preparation of bioactive compounds. Once again, let me reiterate what an honor it has been for me to act as Guest Editor of this Special Issue. I would like to thank all of the authors participating in it, as well as all of the reviewers for providing me with their valuable comments. Finally, I cannot refrain from thanking all of the staff of the Catalysts Editorial Office, especially Caroline Zhan, Associated Editor, whose efforts made this Special Issue possible.

Funding: This research received no external funding.

Conflicts of Interest: The authors declare no conflict of interest. 


\section{References}

1. Truppo, M.D. Biocatalysis in the Pharmaceutical Industry: The Need for Speed. ACS Med. Chem. Lett. 2017, 8, 476-480. [CrossRef] [PubMed]

2. Faber, K. Biotransformations in Organic Chemistry: A Textbook, 7th ed.; Springer International Publishing AG: Cham, Switzerland, 2018. [CrossRef]

3. Bezborodov, A.M.; Zagustina, N.A. Enzymatic Biocatalysis in Chemical Synthesis of Pharmaceuticals (Review). Appl. Biochem. Microbiol. 2016, 52, 237-249. [CrossRef]

4. Hoyos, P.; Pace, V.; Hernáiz, M.J.; Alcántara, A.R. Biocatalysis in the Pharmaceutical Industry. A greener future. Curr. Green Chem. 2014, 1, 155-181. [CrossRef]

5. Lopez-Iglesias, M.; Mendez-Sanchez, D.; Gotor-Fernandez, V. Native Proteins in Organic Chemistry. Recent Achievements in the Use of Non Hydrolytic Enzymes for the Synthesis of Pharmaceuticals. Curr. Org. Chem. 2016, 20, 1204-1221. [CrossRef]

6. Patel, R.N. Applications of Biocatalysis for Pharmaceuticals and Chemicals. In Organic Synthesis Using Biocatalysis; Stewart, J.D., Ed.; Elsevier: Amsterdam, The Netherlands, 2016; pp. 339-411. [CrossRef]

7. Patel, R.N. Pharmaceutical Intermediates by Biocatalysis: From Fundamental Science to Industrial Applications. In Applied Biocatalysis: From Fundamental Science to Industrial Applications; Wiley-VCH GmbH \& Co. KGaA: Weinheim, Germany, 2016; pp. 367-403. [CrossRef]

8. Patel, R.N. Green Processes for the Synthesis of Chiral Intermediates for the Development of Drugs. In Green Biocatalysis; John Wiley \& Sons, Inc.: Hoboken, NJ, USA, 2016; pp. 71-114. [CrossRef]

9. Hoyos, P.; Pace, V.; Alcántara, A.R. Chiral Building Blocks for Drugs Synthesis via Biotransformations. In Asymmetric Synthesis of Drugs and Natural Products; Nag, A., Ed.; CRC Press: Boca Raton, FL, USA, 2018; pp. 346-448.

10. Alcántara, A.R. Biotransformations in Drug Synthesis: A Green and Powerful Tool for Medicinal Chemistry. J. Med. Chem. Drug Des. 2018, 1, 1-7.

11. Sun, H.; Zhang, H.; Ang, E.L.; Zhao, H. Biocatalysis for the synthesis of pharmaceuticals and pharmaceutical intermediates. Bioorg. Med. Chem. 2018, 26, 1275-1284. [CrossRef] [PubMed]

12. Rosenthal, K.; Lutz, S. Recent developments and challenges of biocatalytic processes in the pharmaceutical industry. Curr. Opin. Green Sustain. Chem. 2018, 11, 58-64. [CrossRef]

13. Patel, R.N. Biocatalysis for synthesis of pharmaceuticals. Bioorg. Med. Chem. 2018, 26, 1252-1274. [CrossRef]

14. Groger, H. Enzyme catalysis in the synthesis of pharmaceuticals. Bioorg. Med. Chem. 2018, 26, 1239-1240. [CrossRef]

15. Li, G.Y.; Wang, J.B.; Reetz, M.T. Biocatalysts for the pharmaceutical industry created by structure-guided directed evolution of stereoselective enzymes. Bioorg. Med. Chem. 2018, 26, 1241-1251. [CrossRef] [PubMed]

16. Adams, J.P.; Brown, M.J.B.; Diaz-Rodriguez, A.; Lloyd, R.C.; Roiban, G.D. Biocatalysis: A Pharma Perspective. Adv. Synth. Catal. 2019, 361, 2421-2432. [CrossRef]

17. Hughes, D.L. Biocatalysis in drug development-highlights of the recent patent literature. Org. Process Res. Dev. 2018, 22, 1063-1080. [CrossRef]

18. Devine, P.N.; Howard, R.M.; Kumar, R.; Thompson, M.P.; Truppo, M.D.; Turner, N.J. Extending the application of biocatalysis to meet the challenges of drug development. Nat. Rev. Chem. 2018, 2, 409-421. [CrossRef]

19. Green, A.P.; Turner, N.J. Biocatalytic retrosynthesis: Redesigning synthetic routes to high-value chemicals. Perspect. Sci. 2016, 9, 42-48. [CrossRef]

20. Hoyos, P.; Hernáiz, M.J.; Alcántara, A.R. Biocatalyzed Production of Fine Chemicals. In Reference Module in Life Sciences; Moo-Young, M., Ed.; Pergamon: Oxford, UK, 2017. [CrossRef]

21. Thompson, M.P.; Penafiel, I.; Cosgrove, S.C.; Turner, N.J. Biocatalysis using immobilized enzymes in continuous flow for the synthesis of fine chemicals. Org. Process Res. Dev. 2019, 23, 9-18. [CrossRef]

22. Bilal, M.; Iqbal, H.M.N. State-of-the-art strategies and applied perspectives of enzyme biocatalysis in food sector-Current status and future trends. Crit. Rev. Food Sci. Nutr. 2019, 1-15. [CrossRef] [PubMed]

23. Bilal, M.; Iqbal, H.M.N. Sustainable bioconversion of food waste into high-value products by immobilized enzymes to meet bio-economy challenges and opportunities-A review. Food Res. Int. 2019, 123, 226-240. [CrossRef] [PubMed] 
24. Raveendran, S.; Parameswaran, B.; Ummalyma, S.B.; Abraham, A.; Mathew, A.K.; Madhavan, A.; Rebello, S.; Pandey, A. Applications of microbial enzymes in food industry. Food Technol. Biotechnol. 2018, 56, 16-30. [CrossRef]

25. Li, C.-J.; Anastas, P.T. Green Chemistry: Present and future. Chem. Soc. Rev. 2012, 41, 1413-1414. [CrossRef]

26. Anastas, P.; Eghbali, N. Green Chemistry: Principles and Practice. Chem. Soc. Rev. 2010, 39, 301-312. [CrossRef]

27. Sheldon, R.A. Fundamentals of green chemistry: Efficiency in reaction design. Chem. Soc. Rev. 2012, 41, 1437-1451. [CrossRef] [PubMed]

28. Dunn, P.J. The importance of Green Chemistry in Process Research and Development. Chem. Soc. Rev. 2012, 41, 1452-1461. [CrossRef] [PubMed]

29. Erythropel, H.C.; Zimmerman, J.B.; de Winter, T.M.; Petitjean, L.; Melnikov, F.; Lam, C.H.; Lounsbury, A.W.; Mellor, K.E.; Jankovic, N.Z.; Tu, Q.S.; et al. The Green ChemisTREE: 20 years after taking root with the 12 principles. Green Chem. 2018, 20, 1929-1961. [CrossRef]

30. Marion, P.; Bernela, B.; Piccirilli, A.; Estrine, B.; Patouillard, N.; Guilbot, J.; Jerome, F. Sustainable chemistry: How to produce better and more from less? Green Chem. 2017, 19, 4973-4989. [CrossRef]

31. Smith, D.J. The Past, Present, and Future of Sustainable Chemistry. ChemSusChem 2018, 11, 5-10. [CrossRef] [PubMed]

32. Kummerer, K. Sustainable Chemistry: A Future Guiding Principle. Angew. Chem. Int. Ed. 2017, 56, 16420-16421. [CrossRef] [PubMed]

33. Anastas, P.T.; Zimmerman, J.B. The United Nations sustainability goals: How can sustainable chemistry contribute? Curr. Opin. Green Sustain. Chem. 2018, 13, 150-153. [CrossRef]

34. Horváth, I.T. Introduction: Sustainable Chemistry. Chem. Rev. 2018, 118, 369-371. [CrossRef]

35. Halpaap, A.; Dittkrist, J. Sustainable chemistry in the global chemicals and waste management agenda. Curr. Opin. Green Sustain. Chem. 2018, 9, 25-29. [CrossRef]

36. Hogue, C. Differentiating green chemistry from sustainable chemistry. Chem. Eng. News 2019, 97, 19.

37. Noce, A.M. Green chemistry and the grand challenges of sustainability. In Green Chemistry Education: Recent Developments; Benvenuto, M.A., Kolopajlo, L., Eds.; Walter De Gruyter Gmbh: Berlin, Germany, 2019; pp. 1-11. [CrossRef]

38. Patel, R.N. Green Biocatalysis; John Wiley \& Sons, Inc.: Hoboken, NJ, USA, 2016. [CrossRef]

39. Sheldon, R.A. Biocatalysis and Green Chemistry. In Green Biocatalysis; John Wiley \& Sons, Inc.: Hoiboken, NJ, USA, 2016; pp. 1-15.

40. Sheldon, R.A.; Woodley, J.M. Role of Biocatalysis in Sustainable Chemistry. Chem. Rev. 2017, 118, 801-838. [CrossRef] [PubMed]

41. Sethi, M.K.; Chakraborty, P.; Shukla, R. Biocatalysis-A Greener Alternative in Synthetic Chemistry. In Biocatalysis: An Industrial Perspective; The Royal Society of Chemistry: Cambrige, UK, 2018; pp. 44-76. [CrossRef]

42. Shoda, S.; Uyama, H.; Kadokawa, J.; Kimura, S.; Kobayashi, S. Enzymes as Green Catalysts for Precision Macromolecular Synthesis. Chem. Rev. 2016, 116, 2307-2413. [CrossRef] [PubMed]

43. Sheldon, R.A.; Brady, D. Broadening the Scope of Biocatalysis in Sustainable Organic Synthesis. ChemSusChem 2019, 12, 2859-2881. [CrossRef] [PubMed]

44. Guajardo, N.; Domínguez de María, P. Continuous biocatalysis in environmentally-friendly media: A triple synergy for future sustainable processes. ChemCatChem 2019, 11, 3128-3137. [CrossRef]

45. Foley, A.M.; Maguire, A.R. The Impact of Recent Developments in Technologies which Enable the Increased Use of Biocatalysts. Eur. J. Org. Chem. 2019, 2019, 3713-3734. [CrossRef]

46. Faber, K.; Fessner, W.D.; Turner, N.J. Biocatalysis: Ready to Master Increasing Complexity. Adv. Synth. Catal. 2019, 361, 2373-2376. [CrossRef]

47. Roschangar, F.; Colberg, J.; Dunn, P.J.; Gallou, F.; Hayler, J.D.; Koenig, S.G.; Kopach, M.E.; Leahy, D.K.; Mergelsberg, I.; Tucker, J.L.; et al. A deeper shade of green: Inspiring sustainable drug manufacturing. Green Chem. 2017, 19, 281-285. [CrossRef]

48. Sheldon, R.A. The E factor 25 years on: The rise of green chemistry and sustainability. Green Chem. 2017, 19, 18-43. [CrossRef]

49. McElroy, C.R.; Constantinou, A.; Jones, L.C.; Summerton, L.; Clark, J.H. Towards a holistic approach to metrics for the 21st century pharmaceutical industry. Green Chem. 2015, 17, 3111-3121. [CrossRef] 
50. Roschangar, F.; Sheldon, R.A.; Senanayake, C.H. Overcoming barriers to green chemistry in the pharmaceutical industry-The Green Aspiration Level [trade mark sign] concept. Green Chem. 2015, 17, 752-768. [CrossRef]

51. Lin, J.-L.; Palomec, L.; Wheeldon, I. Design and Analysis of Enhanced Catalysis in Scaffolded Multienzyme Cascade Reactions. ACS Catal. 2014, 4, 505-511. [CrossRef]

52. Sigrist, R.; da Costa, B.Z.; Marsaioli, A.J.; de Oliveira, L.G. Nature-inspired enzymatic cascades to build valuable compounds. Biotechnol. Adv. 2015, 33, 394-411. [CrossRef] [PubMed]

53. O'Reilly, E.; Turner, N.J. Enzymatic cascades for the regio- and stereoselective synthesis of chiral amines. Perspect. Sci. 2015, 4, 55-61. [CrossRef]

54. Schrittwieser, J.H.; Velikogne, S.; Hall, M.; Kroutil, W. Artificial Biocatalytic Linear Cascades for Preparation of Organic Molecules. Chem. Rev. 2017, 118, 270-348. [CrossRef] [PubMed]

55. Bornscheuer, U.T. (Chemo-) enzymatic cascade reactions. Z. Naturforsch. C 2019, 74, 61-62. [CrossRef] [PubMed]

56. Ruales-Salcedo, A.V.; Higuita, J.C.; Fontalvo, J.; Woodley, J.M. Design of enzymatic cascade processes for the production of low-priced chemicals. Z. Naturforsch. C 2019, 74, 77-84. [CrossRef] [PubMed]

57. Groger, H.; Schallmey, A.; Schwab, H.; Kourist, R. Multi-enzyme cascades as synthetic tool for biocatalysis. J. Biotechnol. 2019, 294, 88. [CrossRef] [PubMed]

58. Rudroff, F. Whole-cell based synthetic enzyme cascades-light and shadow of a promising technology. Curr. Opin. Chem. Biol. 2019, 49, 84-90. [CrossRef]

59. Woodley, J.M. Scale-Up and Development of Enzyme-Based Processes for Large-Scale Synthesis Applications. In Biocatalysis in Organic Synthesis; Faber, K., Fessner, W.D., Turner, N.J., Eds.; Georg Thieme: Stuttgart, Germany, 2015; pp. 515-546. [CrossRef]

60. Ramesh, H.; Nordblad, M.; Whittall, J.; Woodley, J.M. Considerations for the Application of Process Technologies in Laboratory- and Pilot-Scale Biocatalysis for Chemical Synthesis. In Practical Methods for Biocatalysis and Biotransformations 3; John Wiley \& Sons, Ltd.: Hoboken, NJ, USA, 2016; pp. 1-30. [CrossRef]

61. Rogers, L.; Jensen, K.F. Continuous manufacturing-The Green Chemistry promise? Green Chem. 2019, 21, 3481-3498. [CrossRef]

62. Lindeque, R.M.; Woodley, J.M. Reactor Selection for Effective Continuous Biocatalytic Production of Pharmaceuticals. Catalysts 2019, 9, 262. [CrossRef]

63. Britton, J.; Majumdar, S.; Weiss, G.A. Continuous flow biocatalysis. Chem. Soc. Rev. 2018, 47, 5891-5918. [CrossRef] [PubMed]

64. Bornscheuer, U.T.; Huisman, G.W.; Kazlauskas, R.J.; Lutz, S.; Moore, J.C.; Robins, K. Engineering the third wave of biocatalysis. Nature 2012, 485, 185-194. [CrossRef]

65. Wang, X.Y.; Wang, B.Y.; Wang, Z.W.; Chen, T.; Zhao, X.M. The Research Progress of Protein Directed Evolution. Prog. Biochem. Biophys. 2015, 42, 123-131.

66. Porter, J.L.; Boon, P.L.; Murray, T.P.; Huber, T.; Collyer, C.A.; Ollis, D.L. Directed evolution of new and improved enzyme functions using an evolutionary intermediate and multidirectional search. ACS Chem. Biol. 2015, 10, 611-621. [CrossRef]

67. Currin, A.; Swainston, N.; Day, P.J.; Kell, D.B. Synthetic biology for the directed evolution of protein biocatalysts: Navigating sequence space intelligently. Chem. Soc. Rev. 2015, 44, 1172-1239. [CrossRef] [PubMed]

68. Renata, H.; Wang, Z.J.; Arnold, F.H. Expanding the Enzyme Universe: Accessing Non-Natural Reactions by Mechanism-Guided Directed Evolution. Angew. Chem. Int. Ed. 2015, 54, 3351-3367. [CrossRef]

69. Denard, C.A.; Ren, H.Q.; Zhao, H.M. Improving and repurposing biocatalysts via directed evolution. Curr. Opin. Chem. Biol. 2015, 25, 55-64. [CrossRef] [PubMed]

70. Porter, J.L.; Rusli, R.A.; Ollis, D.L. Directed Evolution of Enzymes for Industrial Biocatalysis. ChemBiochem 2016, 17, 197-203. [CrossRef]

71. Davis, A.M.; Plowright, A.T.; Valeur, E. Directing evolution: The next revolution in drug discovery? Nat. Rev. Drug Discov. 2017, 16, 681-698. [CrossRef]

72. Bornscheuer, U.T.; Hauer, B.; Jaeger, K.E.; Schwaneberg, U. Directed evolution empowered redesign of natural proteins for the sustainable production of chemicals and pharmaceuticals. Angew. Chem. Int. Ed. 2019, 58, 36-40. [CrossRef]

73. Zeymer, C.; Hilvert, D. Directed evolution of protein catalysts. In Annual Review of Biochemistry; Kornberg, R.D., Ed.; Annual Reviews: Palo Alto, CA, USA, 2018; Volume 87, pp. 131-157. 
74. Arnold, F.H. Directed Evolution: Bringing New Chemistry to Life. Angew. Chem. Int. Ed. 2018, 57, 4143-4148. [CrossRef]

75. Reetz, M.T. Directed Evolution of Selective Enzymes: Catalysts for Organic Chemistry and Biotechnology; Wiley-VCH: Weinheim, Germany, 2017.

76. Illanes, A. Dr. Frances Arnold is awarded with the Nobel Prize in Chemistry 2018: Good news for biocatalysis. Electron. J. Biotechnol. 2018, 36, A1. [CrossRef]

77. Jones, C.W. Another Nobel Prize for Catalysis: Frances Arnold in 2018. ACS Catal. 2018, 8, 10913. [CrossRef]

78. Poppe, L.; Vertessy, B.G. The Fourth Wave of Biocatalysis Emerges The 13th International Symposium on Biocatalysis and Biotransformations. ChemBiochem 2018, 19, 284-287. [CrossRef]

79. Bornscheuer, U.T. The fourth wave of biocatalysis is approaching. Philos. Trans. R. Soc. A Math. Phys. Eng. Sci. 2018, 376, 7. [CrossRef]

80. Sheldon, R.A.; Brady, D. The limits to biocatalysis: Pushing the envelope. Chem. Commun. 2018, 54, 6088-6104. [CrossRef]

81. Woodley, J.M. Accelerating the implementation of biocatalysis in industry. Appl. Microbiol. Biotechnol. 2019, 103, 4733-4739. [CrossRef]

82. Benito-Arenas, R.; Zarate, S.G.; Revuelta, J.; Bastida, A. Chondroitin sulfate-degrading enzymes as tools for the development of new pharmaceuticals. Catalysts 2019, 9, 322. [CrossRef]

83. Hoyos, P.; Pace, V.; Alcántara, A.R. Biocatalyzed synthesis of statins: A sustainable strategy for the preparation of valuable drugs. Catalysts 2019, 9, 260. [CrossRef]

84. Kriaa, A.; Bourgin, M.; Mkaouar, H.; Jablaoui, A.; Akermi, N.; Soussou, S.; Maguin, E.; Rhimi, M. Microbial reduction of cholesterol to coprostanol: An old concept and new insights. Catalysts 2019, 92, 167. [CrossRef]

85. Santos-Moriano, P.; Kidibule, P.; Miguez, N.; Fernandez-Arrojo, L.; Ballesteros, A.O.; Fernandez-Lobato, M.; Plou, F.J. Tailored enzymatic synthesis of chitooligosaccharides with different deacetylation degrees and their anti-inflammatory activity. Catalysts 2019, 9, 405. [CrossRef]

86. Yuan, S.; Xu, Y.L.; Yang, Y.; Kong, J.Q. OcUGT1-catalyzed glucosylation of sulfuretin yields ten glucosides. Catalysts 2018, 8, 416. [CrossRef]

87. Muniz-Mouro, A.; Gullon, B.; Lu-Chau, T.A.; Moreira, M.T.; Lema, J.M.; Eibes, G. Laccase activity as an essential factor in the oligomerization of rutin. Catalysts 2018, 8, 321. [CrossRef]

88. Verdasco-Martin, C.M.; Echevarrieta, L.; Otero, C. Advantageous preparation of digested proteic extracts from Spirulina platensis biomass. Catalysts 2019, 9, 145. [CrossRef]

89. Pinto, A.; Serra, I.; Romano, D.; Contente, M.L.; Molinari, F.; Rancati, F.; Mazzucato, R.; Carzaniga, L. Preparation of sterically demanding 2,2-disubstituted-2-hydroxy acids by enzymatic hydrolysis. Catalysts 2019, 9, 113. [CrossRef]

90. Rabuffetti, M.; Bavaro, T.; Semproli, R.; Cattaneo, G.; Massone, M.; Morelli, C.F.; Speranza, G.; Ubiali, D. Synthesis of ribavirin, tecadenoson, and cladribine by enzymatic transglycosylation. Catalysts 2019, 9, 355. [CrossRef]

91. Gonzalez-Martinez, D.; Fernandez-Saez, N.; Cativiela, C.; Campos, J.M.; Gotor-Fernandez, V. Development of biotransamination reactions towards the 3,4-dihydro-2H-1,5-benzoxathiepin-3-amine enantiomers. Catalysts 2018, 8, 470. [CrossRef]

92. Gacs, J.; Zhang, W.Y.; Knaus, T.; Mutti, F.G.; Arends, I.; Hollmann, F. A photo-enzymatic cascade to transform racemic alcohols into enantiomerically pure amines. Catalysts 2019, 9, 305. [CrossRef]

(C) 2019 by the author. Licensee MDPI, Basel, Switzerland. This article is an open access article distributed under the terms and conditions of the Creative Commons Attribution (CC BY) license (http://creativecommons.org/licenses/by/4.0/). 